\title{
Factors Determining E-Consumer Behavior: An Empirical Research on the Theory of Planned Behavior (TPB)
}

\author{
HATICE ELANUR KAPLAN \\ Niğde Ömer Halidemir University, Niğde Vocational School of Social Sciences, Banking, Finance and \\ insurance Department, Niğde, Turkey. \\ Email: haticeelanurkaplan@ohu.edu.tr \\ Tel: 05345189745
}

\begin{abstract}
This research study is conducted in order to empirically reveal the factors affecting the online purchasing behaviors of university students who act as e-consumers on the Internet and the relationship between these factors within the scope of the theory of planned behavior. The questionnaire survey forms prepared within the context of the theory of planned behavior for this purpose are applied to 327 students who study at Niğde Ömer Halisdemir University in 2017-2018 academic years. The obtained data are analyzed via SPSS 22.0 statistical computer software. In the study, regression analysis is performed in testing the presented model within the theory of planned behavior. As a result of the research study; it is determined that purchase intentions, attitudes/behaviors, and perceived behavioral controls of e-consumers have a positive impact on their purchasing behaviors. Also, the perceived behavioral controls positively affect the direct purchasing behavior and the purchase intention variable also affect the purchasing behavior positively. It is determined that the has no significant impact on purchase intention. Consequently, the empirical results support the theoretical model, except for the aspect of perceived social pressure.
\end{abstract}

Keywords: E-consumer, Online Shopping, Purchasing over the Internet, Purchasing Behavior, Theory of Planned Behavior.

\section{Introduction}

Today, as rapidly advanced communication technologies enter into social and economic life more and more, the Internet has become an indispensable means of communication. The Internet can be defined as a computerized system that allows millions of computer units to interact with each other and to exchange data, messages, and documents with any of these units (Allen, 1998: 2). In parallel with the development of the Internet use and communication technologies, a new economic order seems to be spreading around the world. In this direction, the markets through which buyers and sellers meet have acquired a different dimension by eliminating the geographical barriers inherently, and all people living in the world have been accepted as customers as the business activities have been carried on the Internet (Civan and Bal, 2002: 1011).

This has led to changes in the concept of consumer towards the emergence of the concept of the electronic consumer (e-consumer) or online consumer. The e-consumer can be described briefly as the consumer who shops over the Internet. Online shopping is comprised of four different types, namely; Business-toBusiness, Business-to-Consumer, Consumer-to-Business, and Consumer-to-Consumer (Saydan, 2008: 387). E-retailing, which is categorized under consumer-to-business type, allows consumers to remotely search, select and purchase the products, services, and related information via the Internet (Murray et al., 2004: 264). 
As of today, millions of people around the world exhibit online purchasing behaviors over the Internet. According to the data of 2016, global e-commerce volume has reached 1.6 trillion USD from 630 billion USD within the last four years, and its share in total retail has increased from $4.2 \%$ to $8.5 \%$ (Kantarc1 et al., 2017). Online shopping is also widespread in Turkey as well as the rest of the World countries. According to the Household Information Technology Usage Survey 2017 of the Turkish Statistical Institute; the prevalence of the Internet use among individuals aged 16-74 is $68.8 \%$, and eight out of ten households have the Internet access.

The rate of online shoppers is 24.9\%. Over the 12-month period covering April 2016 and March 2016, $62.3 \%$ of the online shoppers purchased clothing and sports equipment, $25.3 \%$ purchased household goods (furniture, toys, home appliances, etc., excluding consumer electronics), $24.1 \%$ purchased travel tickets, car rentals, etc., $21.9 \%$ purchased food and daily necessity items, and 19\% purchased electronic devices (mobile phone, camera, radio, TV, DVD player, etc.) (TUiK, 2017).

Individual purchasing behaviors take place in two distinct ways; planned and unplanned. Unplanned behavior involves the purchase made as the result of an impulse with no initial purchasing intention (Odabaşı ve Barış, 2002; 377). Planned purchasing, however, occurs along with pre-purchase planning (i.e. intention); specification of the product, the brand, the product category, the product class, and a general need (Odabaşı ve Barış, 2002; 377). Some theories have been developed to explain the planned purchasing behaviors of consumers. One of these theories is the theory of planned behavior (TPB). The theory of planned behavior is regarded as one of the important theories interpreting human behavior in social psychology literature (Başbuğ, 2008: 30). The theory of planned behavior argues that the cognitive process is a logical consequence of the factors determining the individual behavior. According to TPB, the social behaviors of people stem from certain reasons and appear in a planned manner. Formation of the "intention" is the prerequisite for the emergence of behavior. Factors affecting this are "Attitude toward the Behavior," "Subjective Norm" and "Perceived Behavioral Control" (Dilek, 2018: 2).

The objective of this study is to empirically examine the purchasing behaviors of consumers (e-consumers) who shop over the Internet within the context of the theory of planned behavior. Upon examining the related literature, there is merely a limited number of research studies which dealt with purchasing behaviors of consumers over the Internet in the context of the theory of planned behavior, even though many studies related to TPB are mostly encountered. While it is expected that the research study would contribute to the literature in this regard, it is also considered to contribute to the businesses in predicting the purchasing behaviors of their target groups and in determining the strategies they apply more effectively and accurately toward the determinants of e-consumer behavior.

\section{Literature Review}

\section{E- Consumer Purchasing Behaviors}

Today, consumers can access all kinds of products or services through online shopping sites over the Internet. Opportunities such as obtaining information about these products and services, comparing prices, shopping over the Internet increase their influence on consumers' behaviors. The Internet offers a variety of products and services that can be matched to the demands of consumers according to their personal preferences, such as the ability to procure them at lower costs and in less time. Throughout the recent years, the increase in the number of e-consumers has been seen to exceed the increase in the number of the Internet users. It suggests that the Internet users are more likely to shop online. This increase is seen not only in the number of e-consumers but also in the volume of online shopping they make over the Internet (Algür and Cengiz, 2011: 3667).

The research claims that shopping over the Internet is the third most popular activity which follows emailing and web surfing ( $\mathrm{Li}$ and Zhang, 2002: 508-517). E-consumer's purchasing behavior is the process 
of buying products or services over the Internet which consists of five phases associated with traditional shopping behaviors. In general, when e-consumers determine the products and services they need in the process of purchasing, they get connected to the Internet and start searching for information about their needs. However, potential consumers are sometimes attracted by the information provided about the products and services they look for instead of actively searching. Then, by evaluating the alternatives, they choose the one that suits their needs the best. Eventually, the purchase is made, and after-sales services are provided (Kaya, 2002: 3).

Consumers are set to assume a new dimension since they seek more alternatives by asking an increasing number of questions regarding the products they wish to purchase. Moreover, consumers are able to use the Internet at each phase of the purchasing process. For instance, advantages that are provided by the Internet include making comparisons among the alternatives regarding price, quality, and other features and sending unlimited inquiries to specialists and sellers in every detail (Kircova, 2005: 66). Hence, e-consumers tend to become more advantageous over businesses by taking control at every phase of their purchasing process.

As a result, consumers are able to attain products and services with better qualities at more affordable prices. Upon considering the behavioral aspect, consumers are as free and comfortable in the virtual environment as they could never have been in the physical environment. They are present in the Internet environment along with the behaviors they exhibit in the physical stores in their daily life. The Internet has rendered the shopping experience as personal as possible. In addition, consumers can examine many online addresses in a much shorter time and make purchases without undergoing much of an effort. It can be said that the most important factor determining consumer behavior in the virtual environment is time-saving (Enginkaya, 2006: 12). Besides its time-saving feature, online shopping over the Internet also offers the possibility of eliminating much of the geographical limitations, much more information, less time and affordability. In addition to all these, it facilitates the provision of services to meet the demands and needs of consumers and the delivery of goods and services to customers with fewer costs and in less time. In this sense, it is essential for businesses to be aware of the reasons why e-consumers shop or do not shop online regarding developing and maintaining services to become more appealing toward their target audiences. In this context, TPB is able to provide researchers and practitioners with important ideas in the process of interpreting the behaviors of individuals, in general, and, in particular, their behaviors towards using or not using the technology.

\section{Theory of Planned Behavior (TPB)}

The Theory of Planned Behavior (TPB) was developed by Fishbein and Ajzen (1975). According to the theory, social behaviors of the individuals stemming from certain reasons are under the control of certain factors, and they occur in a planned manner. The establishment of the aim towards the behavior is required in order for a behavior to be exhibited by an individual. The factors influencing behavioral intention include attitude toward the behavior, subjective norms and perceived behavioral control (Koç and Turan, 2014: 165). In behavioral research studies, the Theory of Planned Behavior is widely and successfully implemented to predict and explain results with high accuracy ratings (Xu et al., 2016: 626). TPB, which is involved in the link between beliefs and behavior, assumes that the best way to explain the emergence of behavior is the concept of 'intention' (Ajzen, 1988: 132). According to this theory, every voluntary behavior can be predicted by the intention of having the behavior. Meaning, intentions are assumed to explain the motivational factors affecting the behaviors (Branchet et al., 2017: 110).

According to TPB, the social behaviors of individuals arise from certain causes and occur in a planned manner. In order for a behavior to emerge, it is essential to form the "intention" first. Factors affecting this are "Attitude Toward the Behavior," "Subjective Norms" and "Perceived Behavioral Control" (Erten, 2002: 220). This relationship is shown in Figure 1 (Ajzen, 1991: 205). The TPB asserts that Actual Usage (AU) behavior of the individuals is determined by the individuals'Behavioral Intentions (BI) through the influences of Attitude (A), Subjective Norm (SN) and Perceived Behavioral Control (PBC) variables. 


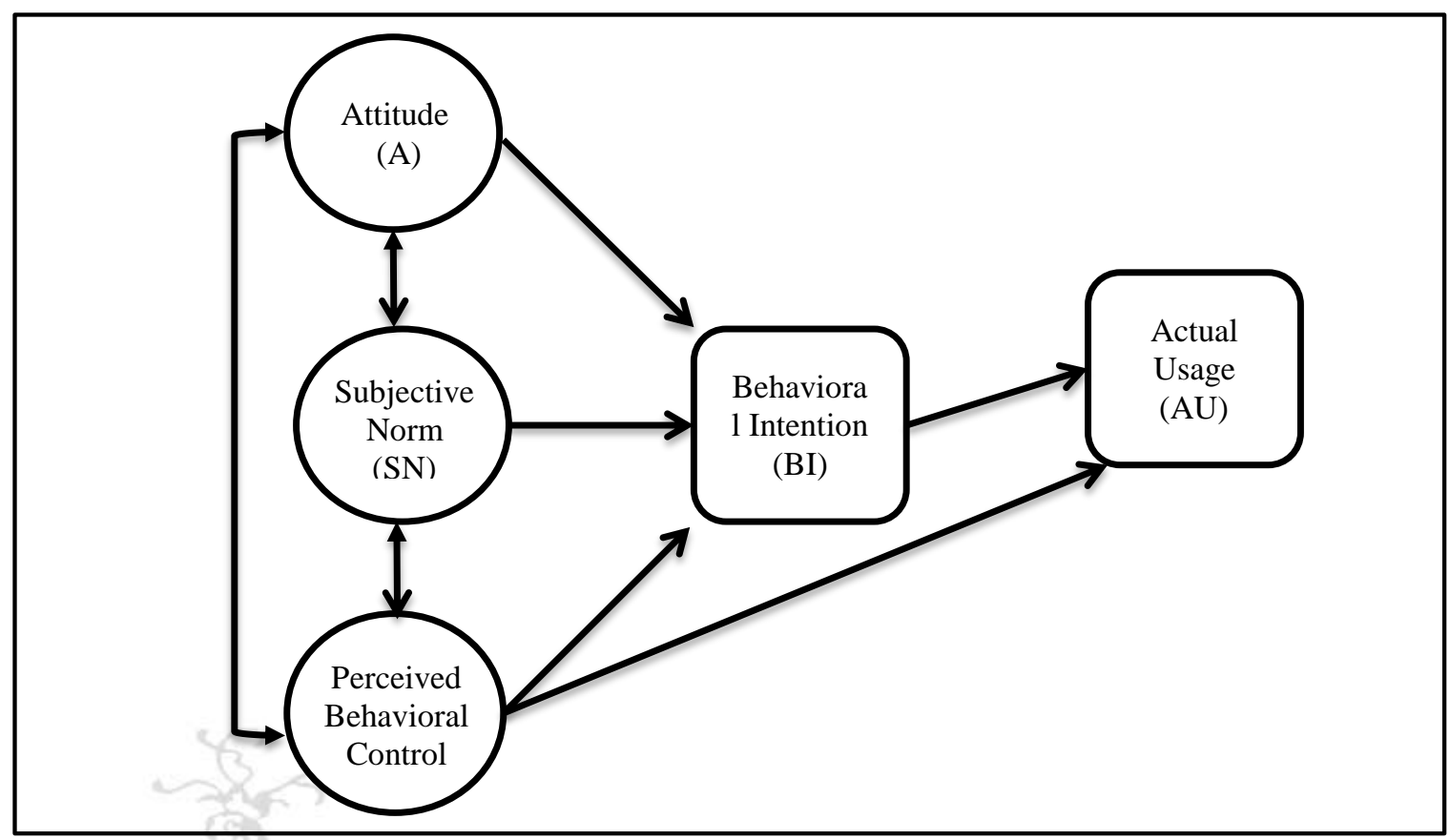

Figure 1. Theory of Planned Behavior (Ajzen, 1991: 182)

Factors that guide human behavior are explained in accordance with the theory follows (Ajzen, 2002b):

- Personal behaviors and attitudes stemming from the behavioral beliefs regarding the possible consequences and their evaluation

- Beliefs about the normative expectations of others and the social pressure created by the motivation to follow these expectations (normative beliefs) - Subjective Norm (perceived social pressure)

- Perceived Behavior Control along with the beliefs (control beliefs) about the behavior and the existence of factors that may facilitate or prevent the perceived power of these factors.

The components included in the theory of planned behavior are summarized briefly as follows:

\section{Actual Behavior}

Many distinct behaviors, which are most likely to be exhibited by consumers from choosing the store/brand to returning the purchased items, involve in the issues of consumer behaviors (Kocagöz, 2010: 33). The theory of planned behavior involves the presentation of this effort as a model. According to TPB, the social behaviors of individuals stem from certain causes and occur in a planned manner. In order for a behavior to emerge, it is first necessary to form the "intention." Factors affecting this include "Attitude toward Behavior," "Subjective Norms" and "Perceived Behavioral Control" (Erten, 2002: 220).

\section{Behavioral Intention}

Intention refers to the tendencies or plans of individuals to either exhibit or not to exhibit the relevant behavior (Kocagöz, 2010: 32). According to Ajzen (2014), the intention of the individual to exhibit the behavior is formed through the attitude towards the behavior, the opinions of people around them 
(subjective norms) and perception that the individual can or cannot exhibit that behavior(perceived behavioral control).

\section{Attitude toward the Behavior}

Attitude leads to the emergence of behavior since it precedes the behavior. Therefore, it is considered to serve as the antecedent to human behaviors (Kalkan, 2011: 194). According to Fishbein and Ajzen (1975), "Attitude toward the Behavior" affects "Intention toward the Behavior," meaning, "Intention." According to Fishbein (2001), attitudes toward the behavior are also expressed as positive or negative feelings and evaluations of a person in relation to the related behavior.

\section{Subjective Norm (Perceived Social Pressure)}

The perception of an individual's social environment in relation to any of the individual's behavior is defined as the 'subjective norm' (Ajzen and Fishbein, 1980: 6). If an individual believes that the reference groups which think that he/she ought to exhibit a certain behavior, he/she feels a social pressure inflicted on himself/herself to perform the behavior. Nonetheless, if the individual happens to believe the exact opposite, then he/she feels obligated not to exhibit the behavior in the sense of social pressure (Albayrak, 2008: 61). In short, individuals are often affected by people in their close proximity. While some choices and decisions they make are private, many of their behaviors are seen by others (Yaşin, 2007: 42). Companies which realize that subjective norms are vital in consumers' decisions to tend to use it successfully in their marketing campaigns (Goldstein and Cialdini, 2009).

\section{Perceived Behavioral Control}

It refers to another important factor in determining intention and is a result of control beliefs. "Perceived Behavior Control" is the self-efficacy that how easy or difficult it is for an individual to exhibit the behavior (Erten, 2002: 222). Perceived behavioral control influences behavior in two ways within the planned behavior model. It can explain the behavior directly through intention and without intention indirectly. When the intention is held constant, it can be directly explained by perceived behavioral control if the effort to reach a successful result is possible by the increase in perceived behavioral control (Kocagöz, 2010: 29). Perceived behavioral control is influenced by control beliefs and control factors. Control beliefs consist of existing factors that reduce and facilitate behavioral performance, and beliefs about the perceived powers of these factors (Bozkurt, 2014: 31). Past experiences about the behavior, outward information, experience of the acquaintances and friends steer the control beliefs (Eyler, 2016: 90). The power of the control factors is the power of the factors to influence the purchasing performance indicated in the control beliefs. The extent to which control belief has the greater contribution in explaining the behavior is determined by the level of perceived power of control factors. For instance; if the store in which discounted products are sold is far away, the power of the control factors determine whether the distance or the discount would be effective on the purchasing desire (Eyler, 2016: 91).

\section{Methodology}

\section{The Research Model and Hypotheses}

The research study is conducted in a correlational survey model to empirically examine the factors which determine e-consumer purchasing behaviors in the context of the theory of planned behavior. "The scanning model is a research approach that aims to describe a past/present situation as it was/is. In the correlational survey models, the attempt is made to determine the existence and magnitude of interchange between two or more variables" (Karasar, 2009: 77). 
The following hypotheses are tested in the research study in accordance with its objective and model:

$\mathrm{H}_{1}$ : The e-consumers' positive purchasing intentions are affected by their positive behaviors and attitudes in this respect.

$\mathrm{H}_{2}$ : The e-consumers' positive purchasing intentions are affected by the positive opinions and thoughts of those in their close proximity.

$\mathrm{H}_{3}$ :The e-consumers' perceived behavioral control ratings has influence on their positive purchasing intentions.

$\mathrm{H}_{4}$ : Formation of purchasing behavioral intention has an effect of e-consumers' purchasing behaviors.

$\mathrm{H}_{5}$ :The degrees of behavioral control have an effect of on e-consumers' purchasing behavior.

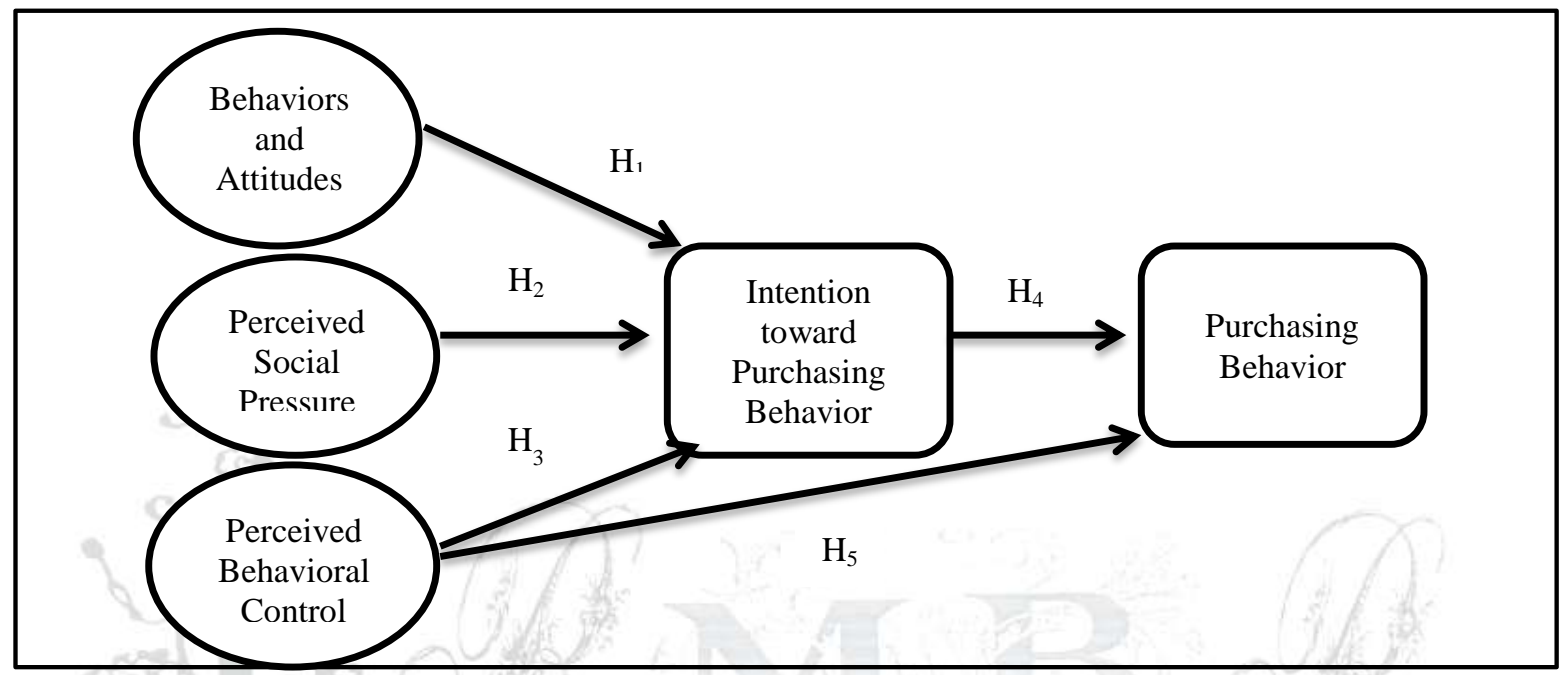

Figure 2. Schematic Model of the Research in Accordance with TPB

\section{The Research Sampling}

The students who are enrolled at Niğde Ömer Halisdemir University located in Niğde Province in 20172018 education year constitutes the population of the research. According to the information obtained from Niğde Ömer Halisdemir University Student Affairs Department, 28,050 students are enrolled in this period. Due to a large number of students, limited time and access opportunities, convenience sampling is applied in the research.

The formula below is utilized for determining the sample size (Salant and Dillman, 1994: 55):

$" \mathrm{n}=\mathrm{N}$ t2 p q / d2 (N-1) + t2pq

$\mathrm{N}$ : Number of individuals in the target audience

$\mathrm{n}$ : Number of individuals included in the sample

p: Frequency of occurrence of an event under examination (probability of occurrence)

q: Frequency of non-occurrence of an event under examination (probability of non-occurrence)

$\mathrm{t}$ : Theoretical value found according to t-table at a certain level of significance

$\mathrm{d}$ : \pm Sampling error determined according to the frequency of occurrence of an event”.

The size of the sample is calculated as $\mathrm{n}=270$ for a non-homogeneous population at $95 \%$ significance level with $\pm 10 \%$ sampling error. In order to obtain more generalized results from survey questionnaires, the questionnaires are applied to even larger number of students, and 327 questionnaire forms are submitted as valid for evaluation. 


\section{Data Collection Tools}

The data are collected via the survey questionnaire method. The questionnaire consists of two parts. In the first part, there are six multiple choice questions to determine the descriptive characteristics (age, gender, etc.) of the students. In the second part, a 5-point Likert-type planned behavior scale consisting of 12 items ( 1 = totally disagree, $5=$ totally agree) organized by Turan (2011) is present to test the theory of planned behavior. Factor dimensions of Turan (2011) are used in the study without performing factor analysis regarding the scale. The scale consists of five dimensions. Both dimensions of behaviors/attitudes and intention toward purchasing behaviors include three items, and two items take place in each dimension of social pressure, perceived behavioral control, and actual use. Reliability analysis of the scale is repeated in the study, and it is determined that the alpha values of reliability for purchasing behavior, the intention toward purchasing behaviors, behaviors/attitudes, social pressure, and perceived behavioral control dimensions are calculated as $0.802,0.842,0.815,0.831$ and 0.823 , respectively. In other words, the scale is reliable.

\section{Statistical Data Analysis}

The data obtained in the study are analyzed using SPSS (Statistical Package for Social Sciences) 22.0 statistical software. Descriptive statistical methods such as number, percentage, mean, standard deviation are used in the evaluation of the data. Relations between the variables in the theory of planned behavior are analyzed by correlation analysis, and their mutual effects are evaluated by regression analysis.

\section{Findings}

The findings obtained from the questionnaires are evaluated in this section. The data on the descriptive characteristics of e-consumers are presented in Table 1.

Table 1. Descriptive Statistics of the Participants

\begin{tabular}{|llcc|}
\hline Variables & Groups & Frequency (n) & $\begin{array}{c}\text { Percentage } \\
(\boldsymbol{\%})\end{array}$ \\
\hline \multirow{2}{*}{ Gender } & Female & 177 & 54.1 \\
& Male & 150 & 45.9 \\
Monthly Income Level & $18-25$ & 264 & 80.7 \\
& 26 and older & 63 & 19.3 \\
& $0-2000$ TL & 255 & 78.0 \\
Educational Status & 2001-3000 TL & 72 & 22.0 \\
& Associate Degree & 224 & 58.8 \\
& Undergraduate & 78 & 23.9 \\
Daily Time Spent Online & Degree & 24 & 7.3 \\
& Graduate & 141 & 43.1 \\
Online Shopping History & $0-2$ Hours & 102 & 31.2 \\
& $3-4$ Hours & 84 & 25.7 \\
\hline Total & 5 Hours and over & 141 & 43.1 \\
\hline
\end{tabular}


According to Table 1; 177 (54.1\%) of the participants are female, and 150 (45.9\%) are male, while 264 (80.7\%) participants are within the age group of 18-25 years and the remaining $63(19.3 \%)$ are 26 years of age and older.

$255(78.0 \%)$ of the participants have monthly incomes between 0-2000 TL, $72(22.0 \%)$ have monthly incomes between 2001-3000 TL, while 225 of the participants (68.8\%) acquire associate degree, 78 $(23.9 \%)$ participants acquire an undergraduate degree, and $24(7.3 \%)$ participants acquire graduate degree. While 141 (43.1\%) participants spend 0-2 hours online per day; 102 (31.2\%) spend 3- 4 hours, and 84 $(25.7 \%)$ spend 5 hours or more online daily. In terms of the shopping history variables; $141(43.1 \%)$ of the participants have been shopping online over the Internet for less than a year, while 96 (29.4\%) and 90 $(27.5 \%)$ of the participants have been shopping online for $1-2$ years, for $3+$ years, respectively. Table 2 contains data on the planned behavior levels of the participants.

Table 2. Data Regarding Planned Behavior Levels of the Participants

\begin{tabular}{|lccccc|}
\hline & N & Mean & Std. Dev. & Min. & Max. \\
\hline Purchasing Behavior & 327 & 2.491 & 1,256 & 1,000 & 5,000 \\
Intention toward the Purchasing Behavior & 327 & 2,575 & 1,326 & 1,000 & 5,000 \\
Behaviors and Attitudes & 327 & 2,593 & 1,349 & 1,000 & 5,000 \\
Perceived Social Pressure & 327 & 2,500 & 1,276 & 1,000 & 5,000 \\
Perceived Behavioral Control & 327 & 2,844 & 1,515 & 1,000 & 5,000 \\
\hline
\end{tabular}

Upon considering the data given in Table 2, it is seen that the mean values of "purchasing behavior" $(2,491$ $\pm 1,256(\operatorname{Min}=1 ; \operatorname{Max}=5))$, "intention toward purchasing behavior" $(2,575 \pm 1,326(\operatorname{Min}=1, \operatorname{Max}=5))$, and "perceived social pressure" $(2,500 \pm 1,276(\operatorname{Min}=1$, Max = 5)) are low; while the mean values of "perceived behavioral control" $(2,844 \pm 1,515(\mathrm{Min}=1, \mathrm{Max}=5))$, and "behaviors and attitudes" $(2,593 \pm$ 1,349 (Min = 1; Max =5)) are medium. These data assert that e-consumers exhibit purchasing behaviors by planning at a low level. Table 3 indicates the correlation analysis data on the relationships among the dimensions included in the planned behavior scale.

Table 3. Correlation Analysis

\begin{tabular}{|c|c|c|c|c|c|c|}
\hline \multirow{3}{*}{$\begin{array}{c}\text { Purchasing } \\
\text { Behavior }\end{array}$} & & $\begin{array}{c}\text { Purchasing } \\
\text { Behavior }\end{array}$ & $\begin{array}{c}\text { Intention toward } \\
\text { the Purchasing } \\
\text { Behavior }\end{array}$ & $\begin{array}{l}\text { Behaviors } \\
\text { and } \\
\text { Attitudes }\end{array}$ & $\begin{array}{l}\text { Perceived } \\
\text { Social } \\
\text { Pressure }\end{array}$ & $\begin{array}{c}\text { Perceived } \\
\text { Behavioral } \\
\text { Control }\end{array}$ \\
\hline & $\mathrm{r}$ & 1.000 & & & & \\
\hline & $\mathrm{p}$ & 0.000 & & & & \\
\hline \multirow{2}{*}{$\begin{array}{l}\text { Intention toward } \\
\text { the Purchasing } \\
\text { Behavior }\end{array}$} & $\mathrm{r}$ & 0.910 ** & 1.000 & & & \\
\hline & $\mathrm{p}$ & 0.000 & 0.000 & & & \\
\hline \multirow{2}{*}{$\begin{array}{c}\text { Behaviors and } \\
\text { Attitudes }\end{array}$} & $r$ & $0.929 * *$ & $0.940 * *$ & 1.000 & & \\
\hline & $\mathrm{p}$ & 0.000 & 0.000 & 0.000 & & \\
\hline \multirow{2}{*}{$\begin{array}{l}\text { Perceived Social } \\
\text { Pressure }\end{array}$} & $\mathrm{r}$ & $0.864 * *$ & $0.862 * *$ & $0.896^{* *}$ & 1.000 & \\
\hline & $\mathrm{p}$ & 0.000 & 0.000 & 0.000 & 0.000 & \\
\hline \multirow{2}{*}{$\begin{array}{c}\text { Perceived } \\
\text { Behavioral } \\
\text { Control }\end{array}$} & $\mathrm{r}$ & $0.820 * *$ & $0.866^{* *}$ & $0.878^{* *}$ & $0.832 * *$ & 1.000 \\
\hline & $\mathrm{p}$ & 0.000 & 0.000 & 0.000 & 0.000 & 0.000 \\
\hline
\end{tabular}

$*<0.05 ; * *<0.01$

Upon examining the correlation among purchasing behavior, intention toward purchasing behavior, behaviors/attitudes, perceived social pressure, and perceived behavioral control given in Table 3; 
- A positive correlation between intention toward purchasing behavior and purchasing behavior is found as $r=0.91(p=0.000<0.05)$,

- A positive correlation between behaviors/attitudes and purchasing behavior is found as $r=0.929$ $(\mathrm{p}=0.000<0.05)$

- A positive correlation between behaviors/attitudes and intention toward purchasing behavior is found as $\mathrm{r}=0.94(\mathrm{p}=0.000<0.05)$,

- A positive correlation between perceived social pressure and purchasing behavior is found as $\mathrm{r}=$ $0.864(\mathrm{p}=0.000<0.05)$,

- A positive correlation between perceived social pressure and intention toward purchasing behavior is found as $\mathrm{r}=0.862(\mathrm{p}=0.000<0.05)$,

- A positive correlation between perceived social pressure and behaviors/attitudes is found as $\mathrm{r}=$ $0.896(\mathrm{p}=0.000<0.05)$,

- A positive correlation between perceived behavioral control and purchasing behavior is found as $r$ $=0.82(\mathrm{p}=0.000<0.05)$,

- A positive correlation between perceived behavioral control and intention toward purchasing behavior in found as $r=0.866(\mathrm{p}=0.000<0.05)$,

- A positive correlation between perceived behavioral control and behaviors/attitudes is found as $\mathrm{r}=$ $0.878(\mathrm{p}=0.000<0.05)$,

- A positive correlation between perceived behavioral control and perceived social pressure is found as $r=0.832(p=0.000<0.05)$.

Table 4 presents the results of regression analysis performed for determining the impacts of the theory of planned behavior on e-consumers' purchasing behaviors.

Table 4. Regression Models of the Theory of Planned Behavior

\begin{tabular}{|c|c|c|c|c|c|c|c|}
\hline Dependent Variable & Independent Variable & B & $\mathbf{t}$ & $\mathbf{p}$ & $\mathbf{F}$ & $\begin{array}{c}\text { Model } \\
\text { (p) }\end{array}$ & $\mathbf{R}^{2}$ \\
\hline \multirow{5}{*}{$\begin{array}{l}\text { Intention toward the } \\
\text { Purchasing Behavior }\end{array}$} & Constant & 0.118 & 2.157 & 0.032 & \multirow{5}{*}{878.291} & \multirow{5}{*}{0.000} & \multirow{5}{*}{0.890} \\
\hline & Behaviors and Attitudes & 0.727 & 15.018 & 0.000 & & & \\
\hline & Perceived Social Pressure & 0.064 & 1.457 & 0.146 & & & \\
\hline & $\begin{array}{l}\text { Perceived Behavioral } \\
\text { Control }\end{array}$ & 0.144 & 4.197 & 0.000 & & & \\
\hline & Constant & 0.271 & 4.295 & 0.000 & & & \\
\hline \multirow[t]{2}{*}{ Purchasing Behavior } & $\begin{array}{l}\text { Intention toward the } \\
\text { Purchasing Behavior }\end{array}$ & 0.862 & 39.584 & 0.000 & 1566.930 & 0.000 & 0.828 \\
\hline & Constant & 0.556 & 6.563 & 0.000 & \multirow[b]{2}{*}{667.747} & \multirow[b]{2}{*}{0.000} & \multirow[b]{2}{*}{0.672} \\
\hline Purchasing Behavior & $\begin{array}{l}\text { Perceived Behavioral } \\
\text { Control }\end{array}$ & 0.680 & 25.841 & 0.000 & & & \\
\hline
\end{tabular}

According to the results of the regression analysis given in Table 4, the regression analysis which is performed to determine the causal relationship between intention toward purchasing behavior and behaviors/attitudes, perceived social pressures, and perceived behavioral control is found to be statistically significant $(\mathrm{F}=878.291, \mathrm{p}=0.000<0.05)$. The $89 \%$ of total variance in intention toward purchasing behavior is explained by behaviors/attitudes, perceived social pressures, and perceived behavioral control $\left(\mathrm{R}^{2}=0.890\right)$. Behaviors/attitudes increase the intention toward purchasing behavior $(\beta=0.727)$. Perceived social pressures do not affect the intention toward purchasing behavior $(\mathrm{p}=0.146>0.05)$. Perceived behavioral control increases the intention toward purchasing behavior $(\beta=0.144)$. Regression analysis is performed to determine the causal relationship between intention toward purchasing behavior and purchasing behavior $(\mathrm{F}=1566.930, \mathrm{p}=0.000<0.05)$. The $82.8 \%$ of total variance in the level of purchasing behavior is explained by the intention toward purchasing behavior $\left(\mathrm{R}^{2}=0.828\right)$. Intention 
toward purchasing behavior increases the level of purchasing behavior $(\beta=0.862)$. Regression analysis is used to determine the causal relationship between perceived behavioral control and purchasing behavior ( $\mathrm{F}$ $=667.747 ; \mathrm{p}=0.000<0.05)$. The $67.2 \%$ of the total variance in the level of purchasing behavior is explained by the perceived behavioral control by $67.2 \%\left(\mathrm{R}^{2}=0.672\right)$. Perceived behavioral control increases the level of purchasing behavior $(\beta=0.680)$. In accordance with the obtained data, the model and the empirical results of this study are presented in Figure 3 below.

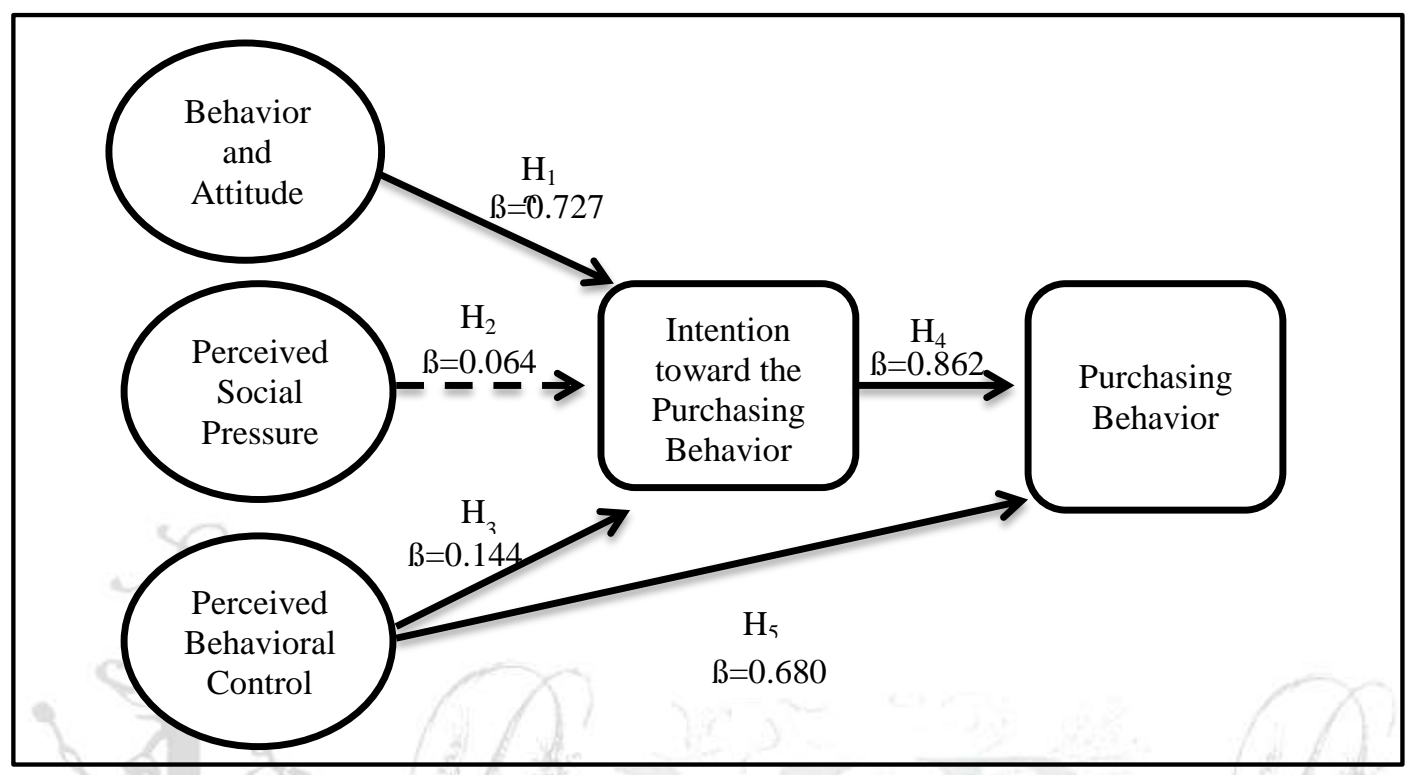

Figure 3. The Empirical Result Model of the Research Study

Upon examining the results of the research model, it is seen that e-consumers' purchasing behaviors in relation to the research hypotheses are influenced by the formation of their intentions on this subject and the magnitude of perceived control on purchasing behavior. Accordingly, the formation of e-consumers' intention toward purchasing behavior is influenced by how positive they perceive purchasing behavior and the magnitude of their perceived behavioral control. However, it is determined that the formation of econsumers' intention toward purchasing behavior is not influenced by perceived social pressure, contrary to what the theory suggests. In other words, all hypotheses that are mentioned at the beginning of the research except for $\mathrm{H}_{2}$ : "The e-consumers' positive purchasing intentions are affected by the positive opinions and thoughts of those in their close proximity." can be accepted.

\section{Conclusion and Discussion}

The main objective of this study is to empirically reveal the factors affecting the purchasing behaviors of university students who are considered as e-consumers and the relationship between these factors within the framework of the theory of planned behavior. Upon considering the research studies that examined online purchasing behavior in Turkey, it is concluded that those studies are mostly conducted on adult individuals, and only a limited number of studies are conducted on university students' online purchasing behaviors within the framework of the socio-psychological theory of planned behavior. Therefore, this study is expected to contribute to the current relevant literature in terms of empirically examining a research model based on TPB unlike other studies conducted on purchasing behaviors. In the study, the variables related to e-consumers' purchasing behaviors in a model of the theory of planned behavior are examined, and it is determined that purchasing behaviors of the participants are not at high levels. This result suggests that consumers usually make unplanned purchases over the Internet. In support of this opinion, Üster (2014) claimed that $81 \%$ - 100\% of online shopping made over the Internet involves 
unplanned purchasing behavior. According to the results of the regression analysis conducted on the model which is revealed in the TPB direction, it is determined that e-consumers' purchasing behaviors have a positive impact on intentions toward purchasing behavior, behaviors/attitudes and perceived behavioral controls.

Furthermore, the perceived behavioral controls positively affect the direct purchasing behavior, and the intention toward purchasing behavior variable also affect the purchasing behavior positively. Therefore, it is determined that as the level of perceived behavioral control and behaviors/attitudes towards purchasing behavior of e-consumers increase, intentions towards purchasing behavior also increase, while intentions toward purchasing behavior increase, purchasing behaviors increase. Moreover, depending on the increase in the level of perceived behavioral control, purchasing behavior is also found to increase. It is seen that the obtained results of the study are in compliance with other relevant studies in the literature.

Ar1, Y1lmaz, and Doğan (2015), which is conducted on the university students using the structural equality model, revealed that perceived behavioral control influenced the intention towards purchasing behavior positively and intention toward purchasing behavior also positively affected online shopping behavior.

Similarly, Turan (2011), which investigated the determinants of consumer behaviors in online shopping by the theory of planned behavior, conclude that behaviors/attitudes and perceived behavioral control affect intention toward purchasing behavior positively, whereas perceived behavioral control and behavioral intention affect online shopping behavior positively. The research study also found that perceived social pressures have no influence on the intention toward purchasing behavior.

The results of some other research studies in the literature (Zhang et al., 2006; Ramus and Nielsen, 2005, Turan, 2011, Doğan et al., 2015) are not consistent with the results of this study due to the fact that they all claimed the existence of perceived social pressure impact on online shopping, notwithstanding certain studies (Ar1, Yılmaz and Doğan, 2015) found that students are not influenced by such pressures in shopping online over the Internet.

It is thought that the reason for the differentiation of research results may be due to different sample groups and the period during which the research studies are conducted. This result suggests that students tend to act more independently without encountering social pressures in making online purchases over the Internet while they are all alone. This study allows an examination of purchasing behaviors within the framework of planned behavior theory by using a sample of university students who act as e-consumers. In the study, the model constructed within the scope of the theory of planned behavior is tested via regression analysis. Similar studies can be conducted by establishing a structural equality model. Furthermore, more research on university students studying at different universities can be carried out, and the obtained data can be compared with the results of this research to attain more generalized data.

\section{References}

Ajzen, I (2002). Constructing A TPB questionnaire: conceptual and methodological considerations.

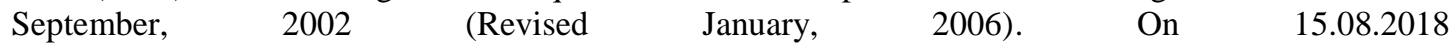
http://people.umass.edu/aizen/pdf/tpb.measurement.pdf, from address accessed

Ajzen, I. (1991). The theory of planned behavior. Organizational Behavior and Human Decision Processes, 50 (2), 179-211.

Ajzen, I. (2014). The theory of planned behaviour is alive and well, and not ready to retire: a commentary on sniehotta, presseau, and araújo-soares. Healt Psychology Review, 9 (2), 131-137.

Ajzen, I. and Fishbein, M. (1980). Predicting and understanding consumer behavior: attitude-behavior correspondence. Ajzen, I. ve Fishbein, M. (Ed.), Understanding Attitudes and Predicting Social Behavior (pp. 148-172). U.S.A: Prentice-Hall. 
Ajzen, I. and Fishbein, M. (1975). Belief, attitude, intention and behavior: an introduction to theory and research. On 15.08.2018 http://people.umass. edu/aizen/f\&a1975.html, 15.08.2018 from address accessed

Albayrak, T. (2008). İşletmelerin Çevrecilik Politikalarının Tüketici Tutum ve Davranışlarına Etkisi. (Basılmamış Doktora Tezi).Akdeniz Üniversitesi Sosyal Bilimler Enstitüsü, Antalya.

Algür, S. ve Cengiz, F (2011). Türk tüketicilere göre online (çevrimiçi) alışverişin riskleri ve Yararları. Journal Of Yaşar University, 22(6), 3666-3680.

Allen, D.W. (1998). Internet ögretim klavuzu. Çeviren: Cahit Akın, İstanbul: Alfa Basım Yayın Dağıtım.

Arı, E., Yılmaz, V., Doğan, M., (2015). Üniversite öğrencilerinin internet üzerinden alışverişlerine ilişkin tutum ve davranışların önerilen bir yapısal eşitlik modeliyle araştırılması, Yönetim ve Ekonomi 22 (2), 385-399.

Başbuğ, G. (2008). Üniversiteden Yeni Mezun Olan Gençlerin İş Arama Davranışlarının Planlı Davranış Teorisi Bağlamında Araştırılması, (Basılmamış Yüksek Lisans Tezi), İstanbul Üniversitesi Sosyal Bilimler Enstitüsü, İstanbul.

Branchet, B. Boissin, J.P. and Hikkerova, L. (2017). Modeling entrepreneurship intentions: an essay of typology. Management International, 21 (2), 109-122.

Civan, M. ve Bal, V. (2002), E-ticaret ve KOBİlerin geleceği. Kocaeli Üniversitesi 1. Ulusal Bilgi, Ekonomi ve Yönetim Kongresi, Bildiriler Kitabı, Kocaeli.

Dilek, Ö. (2007). Şehirlerarası Havayolu Talep Tahmini: Erzurum Üzerine Bir Uygulama, (Basılmamış Yüksek Lisans Tezi), Atatürk Üniversitesi Sosyal Bilimler Enstitüsü, Erzurum.

Doğan, M., Şen, R. and Yılmaz, V. (2015). İnternet bankacılığına ilişkin davranışların planlanmış davranış teorisi ve teknoloji kabul modeli kullanılarak önerilen bir yapısal eşitlik modeliyle incelenmesi. Uşak Üniversitesi Sosyal Bilimler Dergisi, 8 (2), 1-22.

Enginkaya, E. (2006). Elektronik perakendecilik ve elektronik alışveriş. Ege Akademik Bakış Dergisi, 6 (1), 10-16.

Erten, S. (2002). Planlanmış davranış teorisi ile uygulamalı öğretim metodu. Hacette Üniversitesi Edebiyat Dergisi, 19 (2), 217-233.

Eyler, N. (2016). 50 Yaş Üstü Bireylerin Planlı Davranış Kapsamında Sağlık Amacıyla Seyahat Etme Niyetlerinin Belirlenmesine İlişkin Bir Araştırma; Ankara Örneği. (Basılmamış Doktora Tezi), Gazi Üniversitesi Sosyal Bilimler Enstitüsü, Ankara.

Fishbein, M. (2001). Encyclopedia of applied psychology. Charles D. Spielberger (Eds.), Intentional Behavior, ( pp. 329-334). Oxford, Boston: Elsevier Academic Press.

Goldstein, N. J. and Cialdini, R. B. (2009). Normative influences on consumption and conservation behaviors. In M. Wanke (Eds), Social Psychology of Consumer Behavior (pp. 273-296). New York: Psychology Press.

Kalkan, A. (2011). Kişisel tutum, öznel norm ve algılanan davranış kontrolünün girişimcilik niyeti üzerindeki etkisi: üniversite öğrencileri üzerine bir uygulama. Süleyman Demirel Üniversitesi Sosyal Bilimler Enstitüsü Dergisi, (14), 189-206.

Kantarcı, Ö., Özalp, M., Sezginsoy, C., Özaşkınlı, O. ve Cavlak, C. (2017). Dijitalleşen dünyada ekonominin itici gücü: e-ticaret. İstanbul: TÜSİAD

Karasar, N. (2009). Bilimsel araştırma yöntemi. Ankara: Nobel Yayın.

Kaya, G. H. (2002). Türk tarım sektöründe e-ticaret firsatlarl ve potansiyel sorunlar. Ankara: T.C. Tarım Ve Köy İşleri Bakanlığı Araştırma Planlama Ve Koordinasyon Kurulu Başkanlığ

Kircova, İ. (2008). Internette pazarlama. İstanbul: Beta

Kocagöz, E. S. (2010). Kadınların Makyaj Malzemelerini Satın Alma Davranışlarının Incelenmesi: Planlanmış Davranış Teorisinin Bir Uygulaması. (Basılmamış Doktora Tezi). Erciyes Üniversitesi Sosyal Bilimler Enstitüsü, Kayseri.

Koç, T. ve Turan. A.H. (2014). Mobil sabis kabul ve kullanımı: sakarya üniversitesinde ampirik bir değerlendirme. Bilgi Ekonomi ve Yönetimi Dergisi, 9 (2), 163-175.

Li. N. and Zhang P.(2002). Consumer online attitudes and behavior: an assessment of research. Eighth Americas Conference on Information Systems, (74), 508-517. 
Liao, Z. and Cheung, M.T. (2001). Internet based e-shopping and consumer attitudes: an empirical study. Information \& Management, (38), 299-306

Murray, E.J., Amorosa, D., and Adelakun, O. (2004). E-commerce infrastructure success factors for small companies in developing economies. Electronic Commerce Research, 4 (3), 263-286.

Odabaşı, Y. Barış, G. (2002). Tüketici davranışı. İstanbul: Mediacat

Ramus, K. and Nelsen, N.A. (2005). Online grocery retailing: what do consumers think? Internet Research, 15 (3), 335-352.

Salant, P. and Dillman, D. A. (1994). How to conduct your own survey. New York: Wiley

Saydan, R. (2008). Tüketicilerin online alışverişe yönelik risk ve fayda algılamaları: geleneksel ve online tüketicilerin karşılaştırılması. Elektronik Sosyal Bilimler Dergisi, 7 (23), 386-402.

Turan, A.H. (2011). İnternet alışverişi tüketici davranışını belirleyen etmenler: planlı davranış teorisi (tbp) ile ampirik bir test. Doğuş Üniversitesi Dergisi, 12 (1), 128-143.

Türkiye İstatistik Kurumu (TUİK) (2017). Hane halkı ve bilişim teknolojileri kullanımı araştırması. On 16.08. 2018 http://www.tuik.gov.tr/PreHaberBultenleri.do?id=24862, from address accessed

Üster, Z. (2014). Elektronik ortamda alışveriş yapan tüketicilerin kontrolsüz satın alma eğilimlerinin incelenmesi: interaktif bir uygulama. Business \& Management Studies: An International Journal, 2 (2), $168-187$

$\mathrm{Xu}, \mathrm{X}$. and Hao, N., Yinghua, Y.(2016). Factors influencing entrepreneurial intentions of chinese secondary school students: an empirical study. Asia Pacific Education Review, 17 (4),625-635.

Yaşin, B. (2007). Tüketicilerin Alışveriş Stilleri İle Tüketim Değerleri Arasındaki İlişkinin Belirlenmesine Yönelik Bir Araştırma, (Basılmamış Doktora Tezi). İstanbul Üniversitesi Sosyal Bilimler Enstitüsü, İstanbul.

Zhang, X., Prybutok, V.R. and Koh, C.E. (2006). The role of impulsiveness in a tam based online purchasing model. Information Resources Management Journal, 19 (2), 54-68.

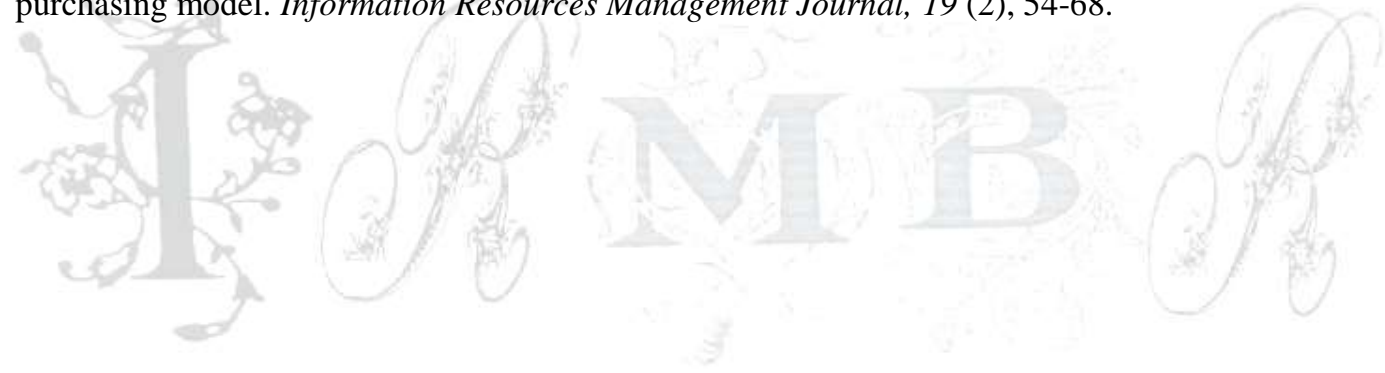

